\title{
EDITORIAL
}

\section{The Journal of Cancer Gene and Cellular Therapies}

Cancer Gene Therapy (2011) 18, 1; doi:10.1038/cgt.2010.74

The field of cellular therapy considerably antedates gene therapy. The British obstetrician James Blundell performed the first successful transfusion of human blood in 1818. The modern era of blood transfusions was born when Reuben Ottenberg administered the first blood transfusion using blood typing and cross-matching in 1907 (http://www.redcrossblood.org/learn-about-blood/ history-blood-transfusion). In the 1950s, E. Donnall Thomas and Georges Mathe pioneered the use of bone marrow transplantation for the treatment of leukemias. ${ }^{1}$

The high efficiency of gene transfer into cells ex vivo is conducive to therapeutic applications. Hence, it was not surprising that the first gene transfer studies in man were performed with genetically engineered cellular autografts. ${ }^{2}$ More recently, the Food and Drug Administration approved the first dendritic cell immunotherapy for cancer (http://www.fda.gov/NewsEvents/Newsroom/ PressAnnouncements/ucm210174.htm). This portends future regulatory approvals for gene therapy applications employing genetically modified dendritic cells, which is the topic of many original research and review articles previously published in Cancer Gene Therapy. Concurrently, identification and applications of pleuripotent progenitor cells in a wide variety of tissues have expanded significantly.

The past and present predict a bright future for numerous and varied applications of combined cellular and gene therapy products. Advances in cellular therapies will improve ipso facto their genetically modified counterparts. Hence, this issue of Cancer Gene Therapy marks the first bearing its new subtitle 'The Journal of Cancer Gene and Cellular Therapies', reflecting the broader scope of articles that the Journal will publish to advance the development of these emerging and converging disciplines.
RE Sobol and KJ Scanlon, Editors PO Box 1574, Rancho Santa Fe, CA 92067, USA E-mail:rsobol@naturecgt.com

\section{References}

1 Mathe G, Thomas ED, Ferrebee JW. The restoration of marrow function after lethal irradiation in man: a review. Transplant Bull 1959; 6: 407-409.

2 Rosenberg SA, Aebersold P, Cornetta K, Kasid A, Morgan RA, Moen $\mathrm{R}$ et al. Gene transfer into humans-immunotherapy of patients with advanced melanoma, using tumor-infiltrating lymphocytes modified by retroviral gene transduction. $N$ Engl J Med 1990; 323(9): 570-578. 